\title{
Communication
}

[Comunicação]

\section{Survival rates of thermotolerant Campylobacter species in a transport and enrichment medium under different environmental conditions}

\author{
[Taxas de sobrevida de espécies termotolerantes de Campylobacter mantidas em um meio de transporte sob \\ diferentes condições ambientais] \\ A. Tresierra-Ayala ${ }^{1}$, C. Grandez ${ }^{1}$, M.E. Bendayan ${ }^{1}$, H. Fernández ${ }^{2 *}$ \\ ${ }^{1}$ Faculdad Ciencias Biológicas - UNAP - Iquitos - Perú \\ ${ }^{2}$ Instituto de Microbiología Clínica - UACh \\ PO Box 567 \\ Valdivia - Chile
}

Thermotolerant campylobacters are important zoonotic agents of human diarrhea, being isolated as enteric pathogens practically in all Central and South America (Fernández, 1992a).

The ability of campylobacters to survive in clinical samples seems to be a difficult event but, if a transport and enrichment medium is used, it should be possible to maintain viable cells for a longer period. Several transport media have been developed for fecal samples (Luechtefeld et al., 1981; Wang et al., 1983; Aho et al., 1988; Fernández, 1992b) and the importance of the transporting power at the same time with the enrichment capacity of some media have been shown (Hutchinson and Bolton, 1983; Sjögren et al., 1985). The use of a transport media might be advantageous (i) for stool samples when campylobacters are present in small numbers, especially when the patient has been treated with antibiotics or when the stool samples can not be processed within $24 \mathrm{~h}$, and (ii) for food and environmental samples. A transport medium is also necessary when rectal swabs are being used, not only because of the small number of bacteria but also because of their increased exposure to oxygen (Palumbo, 1986).

Fernández (1992b) evaluated an enrichment medium (TEC) for the isolation of thermotolerant Campylobacter species. This medium was also used as a transport medium for both human and animal fecal samples as well as for pure cultures of campylobacters, with good results. However, there is no information about the best atmospheric conditions for maintaining viable cells during transport. For this reason, the optimal atmospheric conditions (temperature and oxygen concentration) for survival of campylobacters in this transport and enrichment medium were determined.

Ten Campylobacter strains (6 C. jejuni subsp. jejuni and $4 C$. coli isolated from chicken and pig feces, respectively) were studied. They were spread on blood agar plates and incubated at $42^{\circ} \mathrm{C}$ for $48 \mathrm{~h}$ under microaerobic conditions. Aliquots $(2 \mathrm{ml})$ of suspensions of each strain prepared in sterile distilled water $\left(10^{9} \mathrm{CFU} / \mathrm{ml}\right)$ were seeded onto $2 \mathrm{ml}$ of TEC medium (Fernández, 1992a) consisting of: Brucella broth $2.8 \mathrm{~g} \%$, agar $0.15 \mathrm{~g} \%$, ferrous sulphate $0.05 \mathrm{~g} \%$, sodium metabisulfite $0.05 \mathrm{~g} \%$, sodium piruvate $0.05 \mathrm{~g} \%$, trimethoprim $1 \mathrm{mg} \%$, rifampicin $1.5 \mathrm{mg} \%$, colistin $1000 \mathrm{IU} \%$, amphotericine $1 \mathrm{mg} \%$ and defibrinated horse blood $3 \mathrm{ml} \%$. The inoculated tubes were incubated at different atmospheric conditions: a) aerobically at room temperature $\left( \pm 28^{\circ} \mathrm{C}\right)$, b) microaerobically at room temperature, c) aerobically under refrigeration $\left(4^{\circ} \mathrm{C}\right)$ and d) microaerobically under refrigeration.

Recebido em 11 de agosto de 2005

Aceito em 2 de maio de 2006

*Corresponding author (autor para correspondência)

E-mail: hfernand@uach.cl

Financial support: FONDECYT 1030245 
Viable counts, carried out using a modified Miles and Misra method (Tresierra-Ayala et al., 1999) were done on $0,1,3,5,7$ and 9 days after inoculation or until no bacterial survival was detected. At selected days, a $0.1 \mathrm{ml}$ sample of TEC medium from each atmospheric conditions was obtained, $\log _{10}$ serially diluted in $0.1 \%$ peptone water and $20 \mu \mathrm{l}$ from each dilution were seeded in quintuplicate on blood agar plates. After $36 \mathrm{~h}$ incubation at $42^{\circ} \mathrm{C}$ under microaerobic conditions, viable counts were determined and the results were corrected using the linear regression method.

The use of transport and enrichment media improves campylobacters isolation procedures contributing to develop more accurate epidemiological studies of these bacteria.

As shown in Table 1, most of the strains were viable over five days in TEC medium, but maintenance under microaerobic conditions at room temperature allowed longer survival periods (between 7 and 15 days). Blaser et al. (1980) reported that campylobacters could be recovered after 3 weeks at $4^{\circ} \mathrm{C}$ from feces containing $6 \times 10^{6}$ to $9 \times 10^{9}$ organisms but, when the same samples were stored at $25^{\circ} \mathrm{C}$, no viable organisms could be recovered after 1 week. Contrarily, Ladrón de Guevara et al. (1989) reported that they lost about $16 \%$ of their positive samples after $24 \mathrm{~h}$ storage at $4^{\circ} \mathrm{C}$. Monhort et al. (1989) reported that campylobacters survive in animal feces at least for $3 \mathrm{~h}$ at $4^{\circ} \mathrm{C}$ but for less than $2 \mathrm{~h}$ at $25^{\circ} \mathrm{C}$ stating that the organisms may be killed by toxic metabolites.

C. coli showed longer periods of viability than $C$. jejuni subsp. jejuni (Table 2). This difference is statistically significant [Snedecor variance $F$ test $(P<0.05)$; Student $t$ test $(P<0.10)]$ for the microaerobic atmosphere plus room temperature storage conditions. Some authors suggested that $C$. coli strains could be more resistant than $C$. jejuni to environmental conditions (TresierraAyala et al., 1999; Fernández et al., 2003) being necessary more studies to elucidate this phenomenon.

Table 1. Survival of Campylobacter jejuni subsp. jejuni and Campylobacter coli strains in TEC medium, under different incubation conditions

\begin{tabular}{|c|c|c|c|c|c|}
\hline \multirow{2}{*}{ Organism } & \multirow{2}{*}{ Strain } & \multicolumn{4}{|c|}{ Survival time (days) } \\
\hline & & $\mathrm{A}-\mathrm{RT}$ & $\mathrm{M}-\mathrm{RT}$ & $\mathrm{A}-\mathrm{RF}$ & M - RF \\
\hline \multirow{6}{*}{ C. jejuni subsp. jejuni } & 1 & 5 & 7 & 3 & 3 \\
\hline & 2 & 5 & 9 & 9 & 5 \\
\hline & 3 & 7 & 9 & 5 & 5 \\
\hline & 4 & 7 & 9 & 7 & 7 \\
\hline & 5 & 7 & 9 & 5 & 5 \\
\hline & 6 & 9 & 10 & 7 & 7 \\
\hline \multirow{4}{*}{ C. coli } & 1 & 10 & 15 & 9 & 9 \\
\hline & 2 & 7 & 10 & 5 & 5 \\
\hline & 3 & 7 & 10 & 5 & 7 \\
\hline & 4 & 10 & 15 & 7 & 7 \\
\hline
\end{tabular}

A-RT: aerobically and room temperature; M-RT: microaerobically $\overline{\text { and room temperature; A-RF: aerobically and refrigeration }}$ temperature; M-RF: microaerobically and refrigeration temperature

Table 2. Average of the survival times of $C$. jejuni subsp. jejuni and $C$. coli strains in TEC medium, under different incubation conditions

\begin{tabular}{lccccc}
\hline & & \multicolumn{3}{c}{ Survival time (days) } \\
\cline { 3 - 6 } Organism & $\mathrm{N}$ & A-RT & M-RT* & A-RF & M-RF \\
\hline C. jejuni subsp. jejuni & 6 & 6.7 & 8.8 & 6.0 & 5.3 \\
C. coli & 4 & 8.5 & 12.5 & 6.5 & 7.0 \\
\hline A & 4 . &
\end{tabular}

$\mathrm{A}=$ aerobically; $\mathrm{RT}=$ room temperature; $\mathrm{M}=$ microaerobically; $\mathrm{RF}=$ refrigeration temperature

* For values in this column only, there is a significant difference $(F$ test, $P<0.05$; Student $t$ test, $P<0.10)$ among the two species. 
In all the atmospheric conditions decreasing of the number of viable cells was observed. This could be because both species are unable to multiply below $30^{\circ} \mathrm{C}$. However, when inoculated TEC medium was incubated at $42^{\circ} \mathrm{C}$, microbial population increased.

Although the highest survival times were obtained microaerobically at room temperature, the use of TEC medium associated to aerobic conditions at room temperature could be an efficient method for transporting samples, especially applicable in field studies, since it avoids the use of special atmosphere and temperature conditions.

Keywords: Campylobacter jejuni subsp. jejuni, C. coli, transport medium

\section{RESUMO}

Determinou-se a sobrevida de Campylobacter jejuni subsp. jejuni e C. coli no meio de transporte e enriquecimento TEC, mantido sob diferentes condições de temperatura e concentração de oxigênio. A sobrevida da maioria das amostras foi superior a cinco dias, obtendo-se os períodos de sobrevida mais prolongados (sete a 15 dias), quando o meio foi incubado em microaerofilia à temperatura ambiente, condições nas quais o tempo de sobrevida de C. coli foi superior ao de C. jejuni subsp. jejuni.

Palavras chave: Campylobacter jejuni subsp. jejuni, C. coli, meio de transporte

\section{REFERENCES}

AHO, M.; KAUPPI, M.; HVIN, J. The stability of small number of campylobacteria in different transport media. Acta Vet. Scand., v.29, p.437-442, 1988.

BLASER, M.J.; BERKOWITZ, I.D.; LAFORCE, F.M. et al. Survival of Campylobacter fetus subsp. jejuni in biological milieus. J. Clin. Microbiol., v.11, p. 309-313, 1980.

FERNANDEZ, H. Increase of Campylobacter isolation rates using an enrichment medium. Rev. Microbiol., v.23, p.5-7, 1992a

FERNANDEZ, H. Thermotolerant Campylobacter species associated with human diarrhoea in Latin America. J. Braz. Assoc. Adv. Sci., v.44, p.39-43, $1992 b$.

FERNANDEZ, H.; OTTH, L.; WILSON, M. Isolation of thermotolerant species of Campylobacter from river water using two collection methods. Arch. Med. Vet., v.35, p.95-97, 2003.

HUTCHINSON, D. N.; BOLTON, F.J. Is enrichment culture necessary for the isolation of Campylobacter jejuni for faeces? J. Clin. Pathol., v.36, p.1350-1352, 1983.

LADRÓN DE GUEVARA, C.; PEREZ-POMATA, M.T.; AGUILA, A. et al. Recovery of
Campylobacter from human faeces stored at $4^{\circ} \mathrm{C}$. Epidemiol. Infect., v.102, p.281-285, 1989.

LUECHTEFELD, N.W.; WANG, W.L.L.; BLASER, M.J. et al. Evaluation of transport and storage techniques for isolation of Campylobacter fetus subsp. jejuni from turkey cecal specimens. J. Clin. Microbiol., v.13, p:438-443, 1981.

MONHORT, J.D.; STILLS, H.F.; BECHNULSEN, S. Effects of sample holding time, temperature and atmosphere on the isolation of Campylobacter jejuni from dogs. J. Clin. Microbiol., v.27, p.1419-1420, 1989.

PALUMBO, SA. Campylobacter jejuni in foods: its occurrence, isolation from foods and injury. J. Food Prot., v.49, p.161-166, 1986.

SJÖGREN, E.; LINDBLOM, G.B.; KAIJSER, B. Optimal transport and enrichment methods for the isolation of Campylobacter jejuni. In: PEARSON, A.D.; SKIRROW, M.B.; LIOR, H. et al. (Eds.) Campylobacter III. London: Public Health Laboratory Service, 1985. p.62-63.

TRESIERRA-AYALA, A.; RUIZ, R.; BENDAYAN, $M$. et al. Survival times of Campylobacter coli in sterilized buffalo milk. J. Vet. Med., v.46, p.141-144, 1999.

WANG, W.L.L.; RELLER, L.B.; SMALLWOOD, B. et al. Evaluation of transport media for Campylobacter jejuni in human fecal specimens. $J$. Clin. Microbiol., v.18, p.803-807, 1983. 